\title{
Smart Broom
}

\section{Vivek Jain, Yash Jasnani, Preet Jota, Yogendra Singh Solanki, Aditya Maheshwari}

\begin{abstract}
This paper aims for designing and executing the advanced development in IOT based systems for real time monitoring on sweeper of smart city. Cleanliness - Everyone's prior concern, Authors have taken initiatives to keep our city clean. Even large no. of sweepers are employed for cleaning purpose but the problem arises when they do not work properly. So, here comes in role our SMART BROOM which will Inform working Hour of sweeper, Location of the sweeper, Monitor Regular Working of Sweeper,Data analysis of the work done ,Assure the cleanliness of streets, Keeping an eye on Doodle worker.
\end{abstract}

Keywords: - Microcontroller, GPS, Accelerometer, Vibration Sensor.

\section{INTRODUCTION}

The cleanness is the major problem of the city. Ansmart broom will played major roll in cleaning of cities. The smart broom provide the information about effective working hours of sweepers with, rating of cleaning, real time location of the sweeper. For that purpose we mount one embedded system on the broom. That embedded system contains vibration sensor, accelerometer, NodeMcu ESP8266 work as a data logger. The motion of the broom is measured with the help of vibration sensor and accelerometer. The location of the sweeper is find out the with help of GPS coordinate of the sweeper mobile.

\section{PROBLEM STATEMENT}

Product is mainly designed keeping in mind the needs of the Municipal Corporation of Cities. The workers mark their attendance and carry their broom sticks but do not reach the desired location or even if they go, they do not work properly and places, even after all the expenses remain to be untidy and ultimately become home for diseases. The product can also be of great use for the residential purpose and MNC's to monitor their cleaning staff for proper cleaning of the premises.

Revised Manuscript Received on March 15, 2020.

Dr. Vivek, Assistant Professor, Techno India NJR Institute of Technology, College, Biliya, Rajasthan, India.

Preet Jhota, Department of Electronics and communication Engineering at Techno India NJR Institute of Technology, College, Biliya, Rajasthan, India.

Yash Jasnani, Department of Electronics and communication Engineering at Techno India NJR Institute of Technology, College, Biliya, Rajasthan, India.

Yogendra Singh Solanki, Asst. Professor, Department of Electronics and Communications, Techno India NJR Institute of Technology, Udaipur, India.

Aditya Maheshwari, Capacity of Project Lead- New Initiative \& Research at Techno India NJR Institute of Technology Udaipur, India.
Objective:

- Inform working Hour of sweeper

- Location of the sweeper

- Monitor Regular Working of Sweeper

- Data analysis of the work done

- Assure the cleanliness of streets

- Keeping an eye on Doodle worker

\section{METHODOLGY}

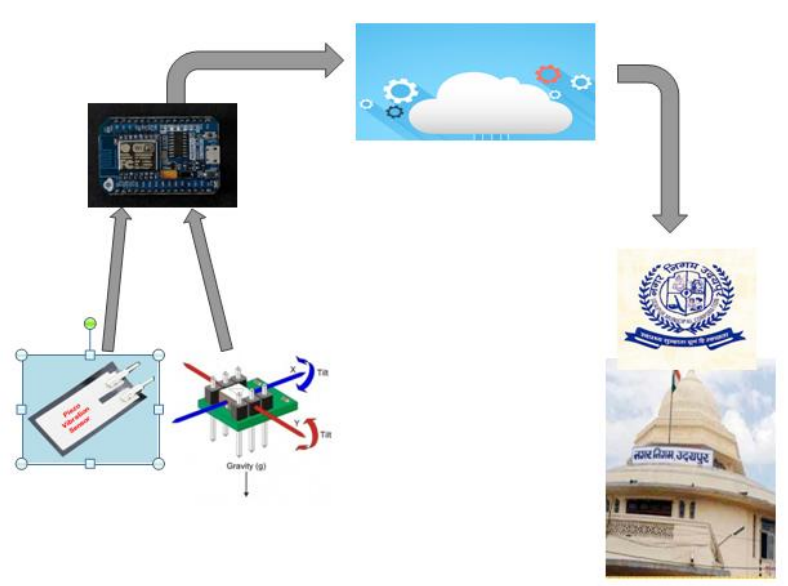

Fig. 1: Flow Chart

Node-MCU ESP8266:Node-MCU is work as controller. It contains analog and digital input-output pins.It also containESP8266 wifi chip. Wifi chip is used for push the data on the cloud. With the help of Node-MCU we read the data from the accelerometer and vibration sensor. According to the values from the sensors we decide the broom in motion or in rest and touch to the ground surface or not.

Vibration Sensor: Vibration sensor worked on the principle of piezoelectric effect. In vibration sensor developed using crystal and seismic mass. Vibration sensor placed at the bottom of broom, when broom will used in cleaning stage at that time crystal is deformed and develop electric potential.Potential is directly proportional to speed of motion of broom.

Accelerometer: The broom acceleration is measured by the accelerometer sensors capacitance. It's contained heavy springmovable in single direction and has fixed outer plates. It attached to the handle of broom, When broom in rest there is no change in the capacitance of accelerometer but broom will be used by sweeper then capacitance of accelerometer will be change .

GPS Location: To find out the GPS location in term of latitude and longitude we used Wi-Fi network. It works on the pre-recorded data online at the time of GPS tracks the location of any object, it also search the strong Wi-Fi networks near it.

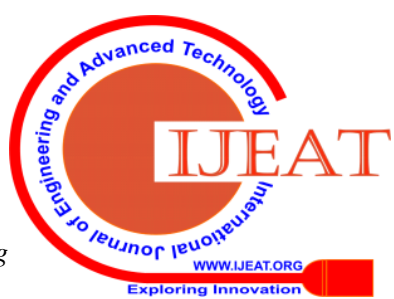




\section{Smart Broom}

In future sweeper will come in this Wi-Fi network his GPS will location also identified with the help of pre-recorded data.

Cloud: After collection of the data from accelerometer, vibration sensor and GPS location we push the data on the thing speak cloud with the help of ESP8266 Wi-Fi Module on Node-MCU.

When sweeper is start working firstly switch on the device on the broom. This time is recorded as start time of cleaning. The data from the accelerometer and vibration sensor will collected by Node-MCU and push to the Thing speak cloud. The existing Wi-Fi network provide GPS location coordinates in term of latitude and longitude parameters. That parameters also push to the thing speak cloud. Authors also note down the switching off time of device. On the basis off switch on time and switch off time authors also find out the total working duration.On the basis of the parameters from the vibration and accelerometer we working duration divided in the three category not cleaning time, medium cleaning time and good cleaning time. On the basis of GPS coordinate we also conclude how much area cleaned by sweeper. All the information will share to the administration of the city.

\section{RESULT}

Table 1: Data from Smart Broom on 2-3-2019

\begin{tabular}{|c|c|c|c|c|}
\hline $\begin{array}{c}\text { created_ } \\
\text { at }\end{array}$ & Accelerometer & Vibration & Longitude & Latitude \\
\hline $\begin{array}{c}\text { 2019-03-02 } \\
13: 21: 26 \\
\text { IST }\end{array}$ & 29 & 0 & 24.51792 & 73.75176 \\
\hline $\begin{array}{c}\text { 2019-03-02 } \\
13: 21: 43 \\
\text { IST }\end{array}$ & 27 & 4 & 24.51792 & 73.75176 \\
\hline $\begin{array}{c}\text { 2019-03-02 } \\
\text { 13:22:00 } \\
\text { IST }\end{array}$ & 28 & 12 & 24.51792 & 73.75176 \\
\hline $\begin{array}{c}\text { 2019-03-02 } \\
\text { 13:22:16 } \\
\text { IST }\end{array}$ & 29 & 7 & 24.51792 & 73.75176 \\
\hline $\begin{array}{c}\text { 2019-03-02 } \\
13: 22: 31 \\
\text { IST }\end{array}$ & 25 & 7 & 24.51792 & 73.75176 \\
\hline $\begin{array}{c}\text { 2019-03-02 } \\
13: 22: 48 \\
\text { IST }\end{array}$ & 21 & 9 & 24.51792 & 73.75176 \\
\hline $\begin{array}{c}\text { 2019-03-02 } \\
\text { 13:23:05 } \\
\text { IST }\end{array}$ & 25 & 8 & 24.51792 & 73.75176 \\
\hline $\begin{array}{c}\text { 2019-03-02 } \\
13: 23: 20 \\
\text { IST }\end{array}$ & 28 & 2 & 24.51792 & 73.75176 \\
\hline $\begin{array}{c}\text { 2019-03-02 } \\
13: 23: 37 \\
\text { IST }\end{array}$ & 27 & 2 & 24.51792 & 73.75176 \\
\hline $\begin{array}{c}2019-03-02 \\
13: 23: 53 \\
\text { IST }\end{array}$ & 27 & 2 & 24.51792 & 73.75176 \\
\hline $\begin{array}{c}2019-03-02 \\
13: 24: 10 \\
\text { IST }\end{array}$ & 28 & 1 & 24.51792 & 73.75176 \\
\hline $\begin{array}{c}2019-03-02 \\
13: 24: 26 \\
\text { IST }\end{array}$ & 29 & 1 & 24.51792 & 73.75176 \\
\hline $\begin{array}{c}2019-03-02 \\
13: 26: 29 \\
\text { IST }\end{array}$ & 19 & 2 & 24.51792 & 73.75176 \\
\hline $\begin{array}{c}\text { 2019-03-02 } \\
13: 26: 46 \\
\text { IST }\end{array}$ & 25 & 2 & 24.51792 & 73.75176 \\
\hline $\begin{array}{c}\text { 2019-03-02 } \\
13: 27: 01 \\
\text { IST }\end{array}$ & 25 & 2 & 24.51792 & 73.75176 \\
\hline $\begin{array}{c}2019-03-02 \\
13: 27: 16\end{array}$ & 31 & 15 & 24.51792 & 73.75176 \\
\hline
\end{tabular}

\begin{tabular}{|c|c|c|c|c|} 
IST & & & & \\
\hline $\begin{array}{c}2019-03-02 \\
13: 27: 33\end{array}$ & & & & \\
IST & 27 & 1 & 24.51792 & 73.75176 \\
\hline $\begin{array}{c}2019-03-02 \\
13: 27: 51\end{array}$ & & & & \\
IST & 31 & 7 & 24.51792 & 73.75176 \\
\hline
\end{tabular}

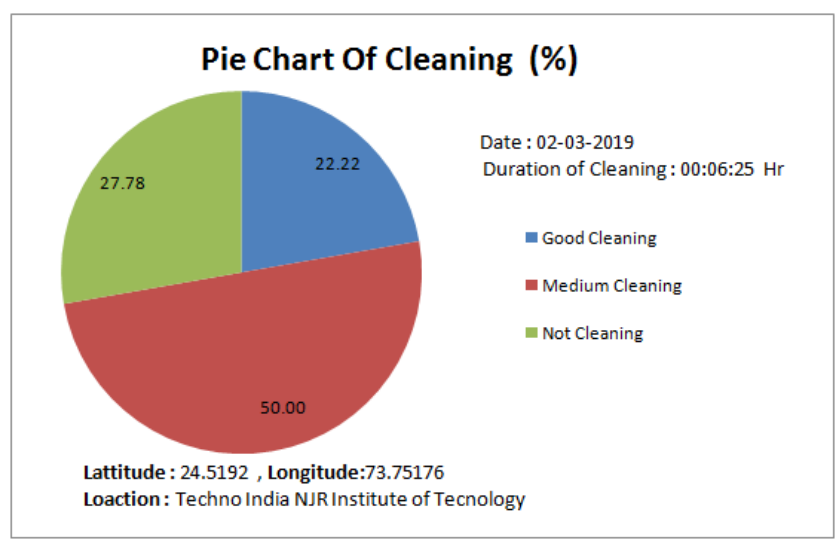

Fig. 2: Pie Chart 1For Data from Smart Broom on 2-32019

Table 2: Data from Smart Broom on 2-3-2019

\begin{tabular}{|c|c|c|c|c|}
\hline $\begin{array}{c}\text { created_ } \\
\text { at }\end{array}$ & Accelerometer & Vibration & Longitude & Latitude \\
\hline $\begin{array}{c}2019-03-02 \\
15: 10: 50 \\
\text { IST }\end{array}$ & 26 & 3 & 24.51792 & 73.75176 \\
\hline $\begin{array}{c}2019-03-02 \\
15: 11: 07 \\
\text { IST }\end{array}$ & 28 & 2 & 24.51792 & 73.75176 \\
\hline $\begin{array}{c}\text { 2019-03-02 } \\
15: 11: 22 \\
\text { IST }\end{array}$ & 29 & 2 & 24.51792 & 73.75176 \\
\hline $\begin{array}{c}\text { 2019-03-02 } \\
\text { 15:11:37 } \\
\text { IST }\end{array}$ & 30 & 2 & 24.51792 & 73.75176 \\
\hline $\begin{array}{c}\text { 2019-03-02 } \\
15: 11: 55 \\
\text { IST }\end{array}$ & 28 & 2 & 24.51792 & 73.75176 \\
\hline $\begin{array}{c}2019-03-02 \\
15: 12: 12 \\
\text { IST } \\
\end{array}$ & 29 & 2 & 24.51792 & 73.75176 \\
\hline $\begin{array}{c}\text { 2019-03-02 } \\
\text { 15:12:29 } \\
\text { IST } \\
\end{array}$ & 29 & 2 & 24.51792 & 73.75176 \\
\hline $\begin{array}{c}2019-03-02 \\
15: 12: 45 \\
\text { IST }\end{array}$ & 29 & 2 & 24.51792 & 73.75176 \\
\hline $\begin{array}{c}\text { 2019-03-02 } \\
\text { 15:13:02 } \\
\text { IST } \\
\end{array}$ & 29 & 2 & 24.51792 & 73.75176 \\
\hline $\begin{array}{c}2019-03-02 \\
15: 30: 15 \\
\text { IST } \\
\end{array}$ & 29 & 2 & 24.51792 & 73.75176 \\
\hline $\begin{array}{c}2019-03-02 \\
15: 30: 31 \\
\text { IST }\end{array}$ & 27 & 2 & 24.51792 & 73.75176 \\
\hline $\begin{array}{c}2019-03-02 \\
15: 30: 49 \\
\text { IST }\end{array}$ & 22 & 5 & 24.51792 & 73.75176 \\
\hline $\begin{array}{c}2019-03-02 \\
15: 31: 06 \\
\text { IST }\end{array}$ & 12 & 7 & 24.51792 & 73.75176 \\
\hline $\begin{array}{c}2019-03-02 \\
15: 31: 23 \\
\text { IST }\end{array}$ & 26 & 4 & 24.51792 & 73.75176 \\
\hline $\begin{array}{c}2019-03-02 \\
15: 31: 40 \\
\text { IST }\end{array}$ & 28 & 2 & 24.51792 & 73.75176 \\
\hline
\end{tabular}

Published By:

Blue Eyes Intelligence Engineering

\& Sciences Publication 


\begin{tabular}{|c|c|c|c|c|}
$\begin{array}{c}2019-03-02 \\
15-31: 58\end{array}$ & & & & \\
IST & 28 & 1 & 24.51792 & 73.75176 \\
\hline $\begin{array}{c}2019-03-02 \\
15: 41: 52 \\
\text { IST }\end{array}$ & & & & \\
\hline $\begin{array}{c}2019-03-02 \\
15: 54: 55 \\
\text { IST }\end{array}$ & 22 & 4 & 24.51792 & 73.75176 \\
\hline
\end{tabular}

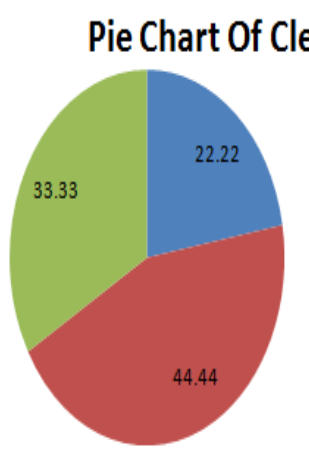

Date: 02-03-2019 Duration of Cleaning:00:44:05

- Good Cleaning

- Medium Cleaning

|- Not Cleaning

Lattitude: 24.5192 , Longitude:73.75176

Loaction: Techno India NJR Institute of Tecnology

Fig. 3: Pie Chart 2 for Data from Smart Broom on 2-32019

Table 3: Data from Smart Broom on 5-3-2019

\begin{tabular}{|l|c|c|c|c|}
\hline \multicolumn{1}{|c|}{ Created at } & $\begin{array}{c}\text { Acceleromete } \\
\mathbf{r}\end{array}$ & $\begin{array}{c}\text { Vibratio } \\
\mathbf{n}\end{array}$ & $\begin{array}{c}\text { Longitud } \\
\mathbf{e}\end{array}$ & Latitude \\
\hline $\begin{array}{l}\text { 2019-03-05 } \\
\text { 15:01:56 IST }\end{array}$ & 19 & 2 & 24.51792 & 73.75176 \\
\hline $\begin{array}{l}\text { 2019-03-05 } \\
\text { 15:02:12 IST }\end{array}$ & 18 & 2 & 24.51792 & 73.75176 \\
\hline $\begin{array}{l}\text { 2019-03-05 } \\
\text { 15:02:28 IST }\end{array}$ & 19 & 3 & 24.51792 & 73.75176 \\
\hline $\begin{array}{l}\text { 2019-03-05 } \\
\text { 15:02:46 IST }\end{array}$ & 20 & 2 & 24.51792 & 73.75176 \\
\hline $\begin{array}{l}\text { 2019-03-05 } \\
\text { 15:03:02 IST }\end{array}$ & 20 & 2 & 24.51792 & 73.75176 \\
\hline $\begin{array}{l}\text { 2019-03-05 } \\
\text { 15:03:19 IST }\end{array}$ & 18 & 2 & 24.51792 & 73.75176 \\
\hline $\begin{array}{l}\text { 2019-03-05 } \\
\text { 15:03:35 IST }\end{array}$ & 20 & 2 & 24.51792 & 73.75176 \\
\hline $\begin{array}{l}\text { 2019-03-05 } \\
\text { 15:03:51 IST }\end{array}$ & 17 & 2 & 24.51792 & 73.75176 \\
\hline $\begin{array}{l}\text { 2019-03-05 } \\
\text { 15:04:07 IST }\end{array}$ & 20 & 7 & 24.51792 & 73.75176 \\
\hline $\begin{array}{l}2019-03-05 \\
\text { 15:04:42 IST }\end{array}$ & 17 & 9 & 24.51792 & 73.75176 \\
\hline
\end{tabular}

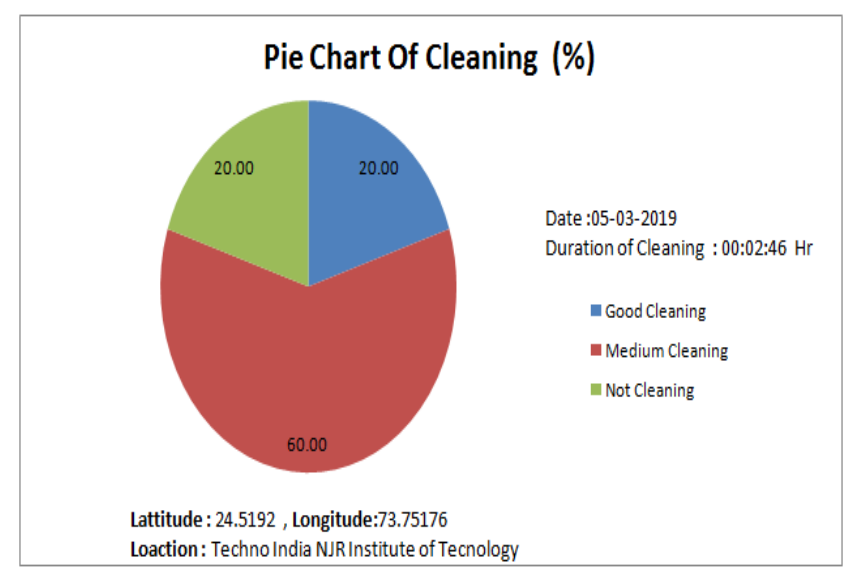

Table 4: Data from Smart Broom on 8-3-2019

\begin{tabular}{|c|c|c|c|c|}
\hline Created at & Accelerometer & Vibration & Longitude & Latitude \\
\hline $\begin{array}{c}2019-03-08 \\
15: 09: 22 \text { IST }\end{array}$ & 28 & 1 & 24.51792 & 73.75176 \\
\hline $\begin{array}{c}2019-03-08 \\
15: 10: 49 \text { IST }\end{array}$ & -74 & 2 & 24.51792 & 73.75176 \\
\hline $\begin{array}{c}2019-03-08 \\
15: 11: 35 \text { IST }\end{array}$ & 31 & 8 & 24.51792 & 73.75176 \\
\hline $\begin{array}{c}2019-03-08 \\
15: 11: 50 \text { IST }\end{array}$ & 24 & 15 & 24.51792 & 73.75176 \\
\hline $\begin{array}{c}2019-03-08 \\
15: 12: 06 \text { IST }\end{array}$ & 26 & 0 & 24.51792 & 73.75176 \\
\hline $\begin{array}{c}2019-03-08 \\
15: 12: 21 \text { IST }\end{array}$ & 27 & 2 & 24.51792 & 73.75176 \\
\hline
\end{tabular}

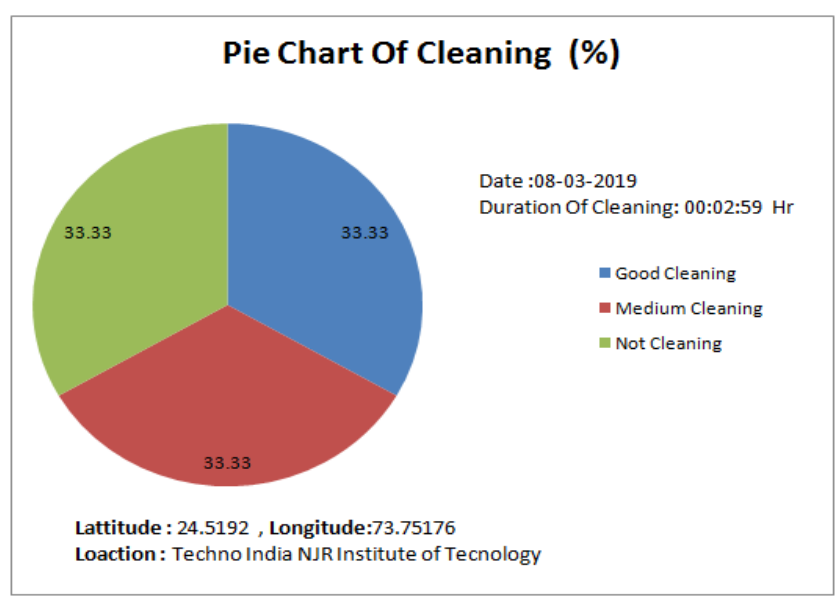

Fig. 5: Pie Chart 4 for Data from Smart Broom on 8-32019

\section{CONCLUSION\& FUTURE WORK}

Proposed system is based on the emerging technologies like IOT and cloud for real-time monitoring on worker. The classification of cleaning based on vibration sensor and accelerometer reading. If vibration sensor reading is less than 2 and difference of two consecutive reading of accelerometer is zero than cleaning count in not cleaning category,If vibration sensor reading is lies between 2 to 5 and difference of two consecutive reading of accelerometer is lies between 1 to 2 than cleaning count in medium cleaning category, If vibration sensor reading is more than 5 and difference of two consecutive reading of accelerometer is more than 3, than cleaning count in medium cleaning category.

Further, the developed work can be extended to apply the machine learning and data analytics on the collected data set to predict the how much area clean by sweeper,create comparison report of sweepers of the system. 


\section{Smart Broom}

\section{REFERENCES}

1. Carrie A. M. Laboski and John B. Peters, "Nutrient Application Guidelines for Field, Vegetable, Fruits and Crops in Wincosin" (A2809), 2013

2. N. V. Hue, R. Uchida, M. C. Ho, "Sampling and Analysis of Plants and Soil Tissues, How to take representative samples, How the samples are tested", in Plant Nutrient Management in Hawaii soils, Approaches for Tropical and Sub-tropical Agriculture, 2014.

3. C. Jones and J. Jacobsen, "Plant Nutrition and Soil Fertility", in Nutrient Management Modules, No. 2, 2014.

4. A Survey on Soil Testing, http://www.vegetablegardener. com/item/2374/soil-testing-savvy”, Accessed on 15th May 2015.

\section{AUTHORS PROFILE}

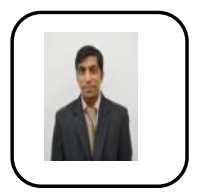

Dr. Vivek Jain has received Ph.D. (Engg.) from MPUAT University 2017. He is working as assistant professor in Techno India NJR Institute of Technology. He has 9 publication. He has supervised one M.Tech. candidates successfully. His field of interest is DSP, IOT and VLSI.

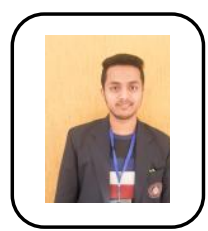

Preet Jhota $3^{\text {rd }}$ year student pursuing B.Tech in Electronics and communication Engineering at Techno India NJR Institute of Technology. His area of interest is in AI, ML and GPU Programming.

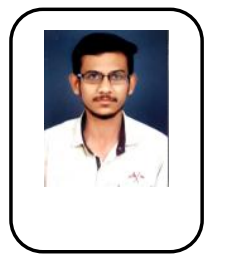

Yash Jasnani $3^{\text {rd }}$ year student pursuing B.Tech in Electronics and communication Engineering at Techno India NJR Institute of Technology. His area of interest is in Analog Electronics.

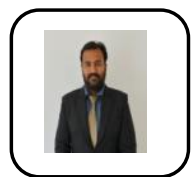

Yogendra Singh Solanki, is working as Asst. Professor, Department of Electronics and Communications, Techno India NJR Institute of Technology, Udaipur. $\mathrm{He}$ is practicing the IoT Devices, AI/ML and VLSI in day to day life.

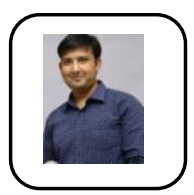

Aditya Maheshwari is working in the capacity of Project Lead- New Initiative \& Research at Techno India NJR Institute of Technology Udaipur. He is an Open Source Advocate, leading technical speaker and Expert of User Research (UI/UX). Leading students by creating and developing projects applying cloud technologies at an engineering institute. Achieved specialization and certification in IBM Watson and Blockchain, and applied in developing projects. 